\title{
Appropriate Analysis and Interpretation Approaches to Determine Fertilizer-derived Nitrogen in Plant Tissues
}

\author{
Timothy L. Righetti ${ }^{1}$, David R. Sandrock, Bernadine Strik, and Anita Azarenko \\ Department of Horticulture, Oregon State University, 4017 ALS Building, Corvallis, OR 97331
}

\begin{abstract}
Additional INDEX wORDs. intercept corrections, ${ }^{15} \mathrm{~N}$, plant nutrition, regression models, stable isotopes
Abstract. Two approaches for estimating the amount of nitrogen (N) in plant tissues derived from labeled fertilizer were evaluated for two tissue types (root and shoot) in three different genera. In the first, atom percentage values obtained by mass spectrometry were converted to the portion of $\mathrm{N}$ derived from the fertilizer (NDFF). In the second, the slope of the regression line for the relationship between total $N$ and labeled fertilizer $N$ was used to represent the incremental increase in fertilizer $\mathbf{N}$ for each unit increase in total $\mathbf{N}$. These two approaches were applied to data collected during container experiments. Unless a plot of total $\mathbf{N}$ versus labeled fertilizer $\mathbf{N}$ passes through the origin, conventional ratio-based estimates of the amount of NDFF for plants or tissues are often misleading. When nonzero intercepts occur, NDFF is dependent on the size (total $\mathbf{N}$ content) of the tissue or plant. Nonzero intercepts were frequently encountered. An analysis of regression lines describing the relationship between total $\mathbf{N}$ gain and fertilizer $\mathbf{N}$ produces a different interpretation than evaluations of the NDFF for treatment means. When an analysis of covariance was used to account for differences in total $\mathrm{N}$ between tissues and genera, results were generally consistent with the graphical observations and regression analysis. If only ratio-based approaches are used, it is difficult to determine if there are real physiological differences among treatments, genera, and tissues or if differences in NDFF are size-related. Because the data easily can be analyzed several ways, simultaneously evaluating data with ratio-based NDFF, covariates, and regression is appropriate.
\end{abstract}

The ratio of labeled fertilizer nitrogen $(\mathrm{N})$ divided by the amount of total $\mathrm{N}$ is a convenient expression for evaluating the amount of $\mathrm{N}$ that is derived from fertilizer. The slope of the regression line for the relationship between total $\mathrm{N}$ and labeled fertilizer $\mathrm{N}$ is also a measure of fertilizer contribution to $\mathrm{N}$ uptake because it represents the incremental increase in fertilizer $\mathrm{N}$ for each unit increase in total $\mathrm{N}$. This article compares slope-based and ratio-based approaches to determine the amount of $\mathrm{N}$ in plants and plant tissues that is derived from labeled $\mathrm{N}$ fertilizer. Mathematical principles inherent in any ratio-based efficiency assessment (Atchley et al., 1976; Packard and Boardman, 1988; Pearson, 1897; Righetti et al., 2007; Tanner, 1949) were evaluated to demonstrate how ratio-based assessments of the amount of $\mathrm{N}$ derived from the fertilizer (NDFF) could be misleading.

Researchers commonly conduct ${ }^{15} \mathrm{~N}$ studies to determine how multiple $\mathrm{N}$ sources (fertilizer, soil, and plant reserves), tissue type, and applied treatments alter the portion of $\mathrm{N}$ that is fertilizer-derived in perennial plant tissues. Atom percentage values obtained by mass spectrometry can be converted to the portion of NDFF using standard conversions (Hauck and Bremner, 1976). The NDFF values for different treatments or genera for either entire plants or individual tissues are commonly compared. When we evaluated citations in the Journal of the American Society for Horticultural Science that dealt with ${ }^{15} \mathrm{~N}$ studies for $2000-2005$, we found that more than $85 \%$ of the published papers presented ratio-based NDFF values

Received for publication 10 Aug. 2006. Accepted for publication 19 Dec. 2006. We thank the following mathematicians for their assistance: Leah Murphy, Oregon State University; Ricardo Baeza and Marie Ines Icaza, University of Talca; and Eric Gottlieb, Rhodes College.

${ }^{1}$ Corresponding author. E-mail: righettt@hort.oregonstate.edu. in tables or figures. Statistically evaluating ratio-based NDFF values has become standard in the $\mathrm{N}$ nutrition literature.

Values of ratio-based expressions are dependent on the value of the denominator if a plot of the denominator versus the numerator of ratio components produces a linear function with a nonzero intercept (Atchley et al., 1976; Packard and Boardman, 1988; Pearson, 1897; Righetti et al., 2007; Tanner, 1949). A ratio-based expression is also mathematically dependent on its denominator if a plot of the log denominator versus $\log$ numerator has a slope that does not equal 1.0 (Brown and West, 2000; Kleiber, 1932; Reich et al., 2006). Packard and Boardman (1988) suggested that ecological physiologists discontinue using ratios to scale data. They proposed using the denominator of a ratio-based expression as a covariate when analyzing the numerator to eliminate indirect effects associated with different sized denominators.

Difficulties in interpreting ratio-based expressions have also been demonstrated in the plant science literature (Meinzer and Zhu, 1998; Ranjith and Meinzer, 1997; Righetti et al., 2007; Sage and Pearcy, 1987; Sandrock et al., 2005). Covariate approaches similar to what Packard and Boardman (1988) suggested have been applied to $\mathrm{N}$ concentration data (Righetti et al., 2007). The inverse of the denominator can also be used as a covariate when a ratio-based expression is evaluated (Righetti et al., 2007).

Sage and Pearcy (1987) proposed evaluating the relationship of the slope of leaf $\mathrm{N}$ content versus total $\mathrm{CO}_{2}$-assimilation regression equation as an alternate measure to traditional ratiobased photosynthetic $\mathrm{N}$ use efficiency (PNUE) evaluations. Slope-based approaches for evaluating PNUE have also been used by other plant researchers to avoid biases in ratio-based expressions (Meinzer and Zhu, 1998; Ranjith and Meinzer, 1997). We suspect that similar issues are important in evaluating 
NDFF, a ratio between labeled fertilizer $\mathrm{N}$ and total $\mathrm{N}$. It is possible that plots of total $\mathrm{N}$ versus labeled fertilizer $\mathrm{N}$ have nonzero intercepts or the slopes of $\log$ total $\mathrm{N}$ versus $\log$ fertilizer $\mathrm{N}$ do not equal one.

We hypothesize that the ratio-based NDFF will often be dependent on the size (dry weight and total $\mathrm{N}$ ) of the tissues or plants that are compared. There are likely to be many statistical differences in mean NDFF and treatment interactions, but it may be difficult to distinguish between size-related differences (indirect) and other physiological differences among treatments, genera, and tissues (direct). Our goal is to demonstrate how graphical observations, regression analyses, and covariate approaches that account for different total $\mathrm{N}$ content among treatments or genera can be helpful tools in discerning the difference between direct and indirect effects.

\section{Materials and Methods}

Slope-based and ratio-based approaches were used to determine the portion of $\mathrm{N}$ in plant tissues that was derived from labeled fertilizer in plants and plant tissues (shoot and root) for young container-grown ornamental plants. This experiment was initiated on very small plants to minimize the quantity of $\mathrm{N}$ reserves. Essentially, all total $\mathrm{N}$ at harvest represented new uptake.

Uniform rooted cuttings of Euonymus alatus (Thunb.) Sieb., E. alatus 'Compactus', Cornus sericea L. 'Cardinal', C. sericea 'Isanti', Weigela florida (Bunge) A. DC. 'Red Prince', and W. florida 'Alexandra' (Wine and Roses) were potted into 3.8-L containers. At planting, 10 plants of each genus were partitioned into shoots and roots, dried, weighed, ground to pass a $0.85-\mathrm{mm}$ sieve, and analyzed for total $\mathrm{N}$ by the Kjeldahl procedure (Horneck et al., 1989). These data were subtracted from final measurements of dry weight and plant $\mathrm{N}$ to determine growth and $\mathrm{N}$ uptake during the experimental period. Because there were no differences between the cultivars within each genus, hereafter the cultivars are referred to as "euonymus," "cornus," and "weigela." Two fast-growing genera, one with a low $\mathrm{N}$ content (cornus $\approx 1 \% \mathrm{~N}$ ) and the other with a high $\mathrm{N}$ content (weigela $\approx 2 \% \mathrm{~N}$ ), are represented. A third slow-growing but high-N genus (euonymus $\approx 2 \% \mathrm{~N}$ ) is also included in the study.

The growing substrate consisted of seven fresh Douglas Fir [Pseudotsuga menziesii (Mirb.) Franco] bark (initial $\mathrm{pH}$ 3.6): 2 sphagnum peatmoss: 1 silica sand $(0.65 \mathrm{~mm})$ by volume. The substrate was amended with $0.883 \mathrm{~kg} \cdot \mathrm{m}^{-3}$ Micromax (The Scotts Co., Marysville, Ohio), $1.77 \mathrm{~kg} \cdot \mathrm{m}^{-3}$ agricultural lime $\left(\mathrm{CaCO}_{3}\right), 1.77 \mathrm{~kg} \cdot \mathrm{m}^{-3}$ dolomite $\left(\mathrm{CaCO}_{3}+\mathrm{MgCO}_{3}\right), 1.05$ $\mathrm{kg} \cdot \mathrm{m}^{-3} 8$ - to 9 -month slow-release phosphorous (The Scotts Co.), and $1.18 \mathrm{~kg} \cdot \mathrm{m}^{-3} 8$ - to 9-month slow-release potassium (The Scotts Co.). Substrate $\mathrm{pH}$ at transplanting (after all amendments were added) was 5.6.

Experiments were conducted outdoors in full sun on a gravel pad at Oregon State University's Lewis Brown Horticulture Farm in Corvallis (lat. $44^{\circ} 30^{\prime} \mathrm{N}$, long. $123^{\circ} 12^{\prime} \mathrm{W}$ ) in a completely randomized design with six single-plant replicates of each of the three genera per treatment. Water used for supplemental irrigation from the horticulture farm had a $\mathrm{NO}_{3}-\mathrm{N}$ concentration of $1.5 \mathrm{mg} \cdot \mathrm{L}^{-1}$.

Treatments consisted of five $\mathrm{N}$ application rates (NAR): $25,50,100,200$, and $300 \mathrm{mg} \cdot \mathrm{L}^{-1}$ delivered as aqueous, doublelabeled ${ }^{15} \mathrm{~N}$ depleted $\mathrm{NH}_{4} \mathrm{NO}_{3}$ (minimum $99.95 \%$ atom ${ }^{14} \mathrm{~N}$;
Isotec, Miamisburg, Ohio). Although a zero rate may have been desirable, past experience suggested that plants have difficulty surviving during the early part of the growth cycle in this bark-based media without some supplemental N. The amounts of $\mathrm{N}$ delivered to each container over the duration of the study at NARs of $25,50,100,200$, and $300 \mathrm{mg} \cdot \mathrm{L}^{-1}$ were $307,615,1230,2460$, and $3690 \mathrm{mg}$, respectively. Treatments began on 9 Apr. and were applied on alternate days until 9 Sept. At each application, each container received the same $\mathrm{N}$ solution volume. During the first 2 months of the experiment, treatments were applied with a Wheaton Unispense Peristaltic Pump (Wheaton Science Products, Millville, N.J.), while volumes were low, and were later applied with $354.8-\mathrm{mL}$ plastic bottles modified to fill and drain to the required amount. From 9 Apr. to 18 May, plants received 100,150, 200, or $250 \mathrm{~mL}$ of fertilizer solution at each treatment as water use increased. From 22 May to $10 \mathrm{Sept}$., plants received $300 \mathrm{~mL} \cdot \mathrm{d}^{-1}$ per container of fertilizer solution at each treatment. Therefore, more water and $\mathrm{N}$ was applied as plants grew. After 16 June, supplemental irrigation was delivered on days when the plants did not receive treatments. Overhead irrigation rates began at $300 \mathrm{~mL} \cdot \mathrm{d}^{-1}$ per container and reached $500 \mathrm{~mL} \cdot \mathrm{d}^{-1}$ per container by 9 Sept. when treatments and irrigation ended. Supplemental irrigation rates were adjusted to maintain a $25 \%$ leaching fraction at each $\mathrm{N}$ solution application throughout the experiment and monitored weekly.

After 15 months, six replications from each genus were destructively harvested and partitioned into roots and shoots. All tissues were dried, weighed, and ground to pass a $0.425-\mathrm{mm}$ sieve. Total $\mathrm{N}$ and isotopic analyses were determined by mass spectrometry at Isotope Services (Los Alamos, N.M.). Atom percent ${ }^{15} \mathrm{~N}$ values were converted to NDFF using the formula adapted from Hauck and Bremner (1976). This traditional measure of NDFF does not reflect the portion of new uptake that is fertilizer-derived because the plants had an initial $\mathrm{N}$ content when the experiment began. An alternate NDFF that reflects the amount of new uptake that was fertilizer-derived was calculated by dividing labeled fertilizer $\mathrm{N}$ content by the total $\mathrm{N}$ gain over the experimental period. In all statistical evaluations, both NDFF expressions suggest the same conclusions. Hereafter, the term NDFF refers to labeled fertilizer $\mathrm{N}$ content divided by the total $\mathrm{N}$ gain.

Log transformations on total $\mathrm{N}$ gain and labeled fertilizer $\mathrm{N}$ content were implemented to meet assumptions concerning variance homogeneity. The NDFF data met assumptions concerning homogeneity of variance; thus, the raw data were analyzed. Data were analyzed as a split plot completely randomized experiment with $\mathrm{N}$ rate and genera as main plots and tissue as a subplot when roots and shoots were compared. Total plant biomass data were analyzed as a completely randomized factorial experiment.

The SAS statistical package (version 9.12; SAS Institute, Cary, N.C.) was used for statistical analyses. The PROC MIXED procedure with a RANDOM statement was used to conduct an analysis of variance (ANOVA) and to make pairwise comparisons of SAS LSMEANS for all split plot analyses. When a split plot analysis that included $\mathrm{N}$ rate was conducted, the subplot factor (tissue type) was treated as a nonindependent correlated factor and a repeated-measures correction was performed in PROC MIXED. Four covariance structures were evaluated; unstructured (UN), compound symmetry (CS), Toeplitz, and autoregressive. Only the UN and CS covariance 
structures met convergence criteria. Because the UN covariance structure produced the smallest Akaike information corrected criterion value, the results from the UN analysis are presented here.

The PROC MIXED procedure was also used to conduct analysis of covariance (ANCOVA) on $\log _{10}$ fertilizer $\mathrm{N}$ content and NDFF with $\log _{10}$ total $\mathrm{N}$ gain and the inverse of total $\mathrm{N}$ gain as the respective covariates. Homogeneity of slopes was tested by determining if the covariates significantly interacted with $\mathrm{N}$ rate, genera and tissue, and their interaction. Homogeneity of slope assumptions was not met when the entire data set was evaluated. Therefore, each $\mathrm{N}$ rate was analyzed independently and interpretations based on an ANOVA on NDFF data and an ANCOVA on $\log _{10}$ fertilizer $\mathrm{N}$ content and NDFF with the covariates described were compared. The individual $\mathrm{N}$ rate ANOVAs and ANCOVAs were analyzed as completely randomized split plot experiments with genera as the main plot and tissue as subplots.

When total plant data were analyzed, the PROC GLM procedure was used to make the ANOVA and ANCOVA analyses and to make pairwise comparisons of SAS LSMEANS as described. Homogeneity-of-slope assumptions were also not met for the total plant data when the entire data set was evaluated. Therefore, each $\mathrm{N}$ rate was analyzed independently as described. The individual $\mathrm{N}$ rate ANOVAs and ANCOVAs for the entire plant data were analyzed as completely randomized experiments for the total plant data.

Because $\mathrm{N}$ rate is an incremental value, the LSMEANS generated as described were used to generate a regression model to determine $\mathrm{N}$ rate effects rather than conducting mean comparisons. Regression analysis was also used to evaluate the relationship between total $\mathrm{N}$ gain and fertilizer $\mathrm{N}$ content for the combined replicate data of all three plant genera at each $\mathrm{N}$ rate. The relationship between NDFF and total $\mathrm{N}$ gain was also evaluated.

The slope of the regression line for the relationship between total $\mathrm{N}$ and labeled fertilizer $\mathrm{N}$ was used to represent the incremental increase in fertilizer $\mathrm{N}$ for each unit increase in total N. As data from increasing application rates are plotted, an increase in slopes reflects the greater portion of $\mathrm{N}$ that is fertilizer-derived. At each $\mathrm{N}$ application rate, the slopes of the regression lines, which included data for all three genera, are referred to as the portions of incremental uptake derived from the fertilizer (IUDF).

\section{Results and Discussion}

Depending on genera, dry weight increased 3.5- to fourfold and $\mathrm{N}$ content increased four- to fivefold with increasing $\mathrm{N}$ rate. Increased dry weight and $\mathrm{N}$ content were apparent even at the two highest $\mathrm{N}$ rates $\left(200\right.$ and $\left.300 \mathrm{mg} \cdot \mathrm{L}^{-1}\right)$. At the end of the growth period, plants in the high $\mathrm{N}$ treatment were 25-, 16-, and fivefold larger than the initial transplants for cornus, weigela, and euonymus, respectively. Details of plant response and fertilizer recovery are reported elsewhere (Sandrock et al., 2005).

Evaluation of MEAN NDFF fOR WhOle Plants. Mean values for whole-plant NDFF significantly increased with $\mathrm{N}$ rate for all three genera (Table 1). Differences among genera are most apparent at the lowest $\mathrm{N}$ rates. Euonymus had significantly higher NDFF than the other two genera at the 25-, 50and $100-\mathrm{mg} \cdot \mathrm{L}^{-1} \mathrm{~N}$ rates. Application rate $\times$ genera interactions are significant $(P<0.001)$. Although clear statistical differences for NDFF between genera are apparent, these differences are probably an indirect and size-related result of nonzero intercepts (discussed subsequently).

REgRESSION EVALUATIONS OF THE PORTION OF NITROGEN DERIVED FROM FERTILIZER FOR WHOLE PLANTS. In Figure 1, the relationship between total $\mathrm{N}$ gain and labeled fertilizer $\mathrm{N}$ is shown for all genera at each of the five $\mathrm{N}$ application rates. Slopes significantly increase with increasing $\mathrm{N}$ rate. This supports the NDFF trends apparent in Table 1 and suggests that $\mathrm{N}$ rate directly alters $\mathrm{N}$ accumulation.

The graphs suggest that the points for all three genera fall on the same line. Slopes and $y$-intercepts for individual genera are not significantly different (data not shown). The poorer (but still good) fit for the low rate (Fig. 1A) may be attributable to an inaccurate estimate of the amount of $\mathrm{N}$ in the original seedlings (averaged values used). The value for the slope represents the amount of $\mathrm{N}$ from fertilizer. For example, at the $100-\mathrm{mg} \cdot \mathrm{L}^{-1}$ rate, $555 \mathrm{mg}{ }^{15} \mathrm{~N}$ is accumulated for every gram of total $\mathrm{N}$.

The relationship between NDFF and total $\mathrm{N}(N D F F=$ $b(1 /$ total $N)+m)$ is defined by the original linear equations (Fig. 1). The $y$-intercepts were positive for all $\mathrm{N}$ levels and

Table 1. Statistical differences for mean values for the portion of total plant nitrogen derived from fertilizer (NDFF) for Cornus sericea (cornus),

Euonymus alatus (euon.), and Weigela florida (weigela) grown in containers at different $\mathrm{N}$ rates. ${ }^{\mathrm{z}}$

\begin{tabular}{|c|c|c|c|c|c|}
\hline \multirow[b]{2}{*}{$\mathrm{N}$ rate $\left(\mathrm{mg} \cdot \mathrm{L}^{-1}\right)$} & \multicolumn{3}{|c|}{ Portion NDFF $\left(g \cdot g^{-1}\right)$} & \multirow[b]{2}{*}{ IUDF $\left(g \cdot g^{-1}\right)$} & \multirow{2}{*}{$\begin{array}{c}\text { Slope log-log } \\
\text { plot }\left[\log g\left(\log g^{-1}\right)\right]\end{array}$} \\
\hline & Cornus & Euon. & Weigela & & \\
\hline 25 & $0.180 \mathrm{a}^{\mathrm{y}}$ & $0.296 \mathrm{~b}$ & $0.198 \mathrm{a}$ & $0.116 \pm 0.041^{\mathrm{x}}$ & $0.444 \pm 0.118^{\mathrm{w}}$ \\
\hline 50 & $0.350 \mathrm{a}$ & $0.495 \mathrm{~b}$ & $0.377 \mathrm{a}$ & $0.287 \pm 0.041$ & $0.632 \pm 0.091$ \\
\hline 200 & $0.770 \mathrm{a}$ & $0.805 \mathrm{a}$ & $0.779 \mathrm{a}$ & $0.763 \pm 0.088$ & $0.929 \pm 0.066$ \\
\hline 300 & $0.873 \mathrm{a}$ & $0.824 \mathrm{a}$ & $0.864 \mathrm{a}$ & $0.870 \pm 0.066$ & $0.989 \pm 0.052$ \\
\hline $\begin{array}{l}\text { Quadratic statistical } \\
\text { significance }\end{array}$ & $* * * \mathrm{v}$ & *** & **** & *** & *** \\
\hline
\end{tabular}

${ }^{z}$ The slope-based incremental uptake of $\mathrm{N}$ derived from the fertilizer (IUDF) and the slope of a $\log _{10}$ total $\mathrm{N}$ gain versus log ${ }_{10}$ fertilizer $\mathrm{N}$ plot are also shown for each $\mathrm{N}$ rate.

${ }^{\mathrm{y}}$ Values for NDFF for different genera in the same row (same $\mathrm{N}$ rate) followed by the same letter are not statistically significant $(P>0.05)$.

${ }^{x}$ Values indicate $95 \%$ confidence level for $P<0.05$.

${ }^{\text {w}}$ Values indicate $95 \%$ confidence level for $P<0.05$. Slopes significantly less than $1.0($ mean $+\mathrm{CI}<1.0)$ indicate that portion NDFF significantly scales (decreases) with total $\mathrm{N}$ gain.

${ }^{\mathrm{v}} \mathrm{A}$ triple asterisk indicates that the quadratic relationship for values in the same column is statistically significant $(P<0.001)$. 

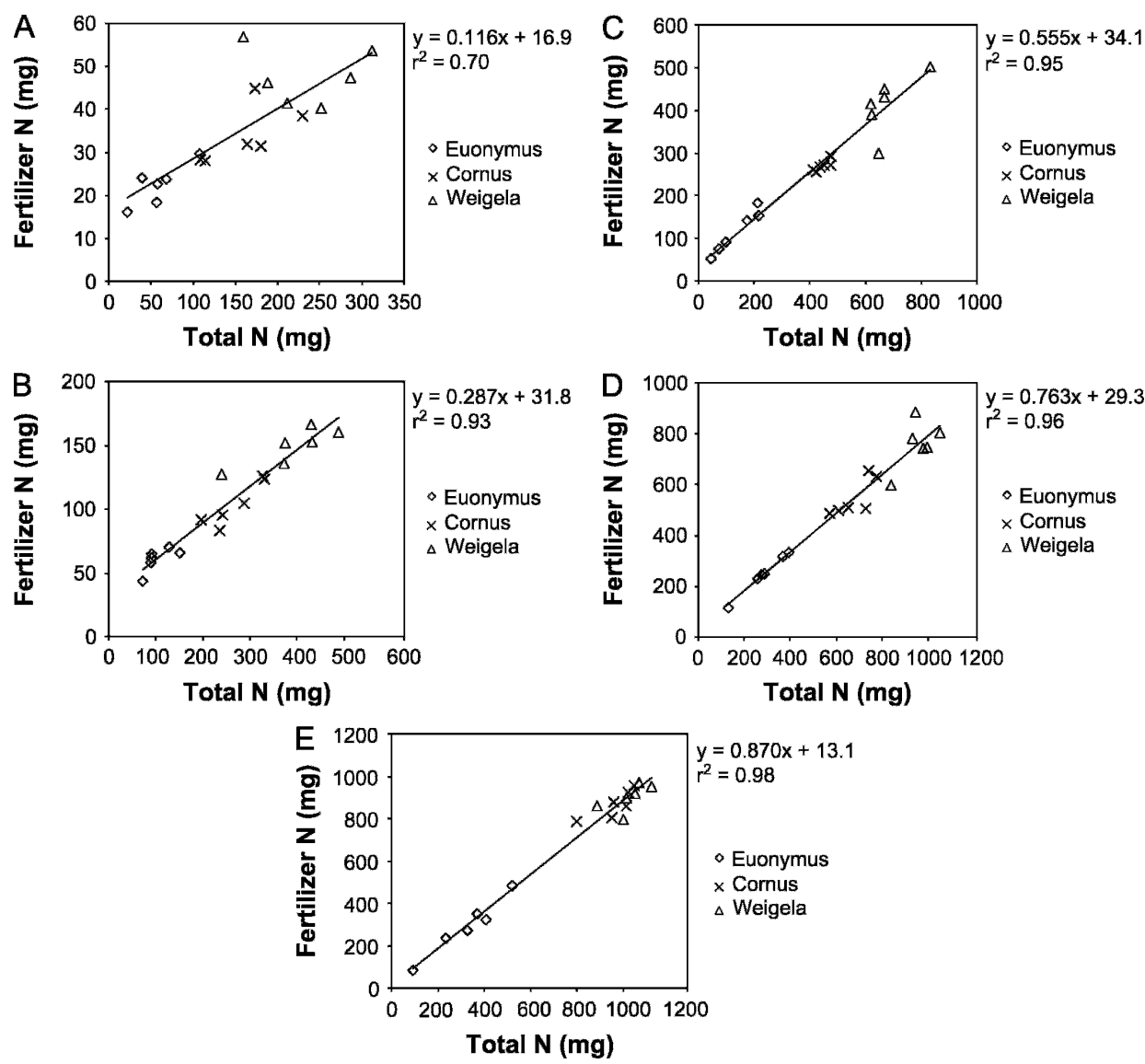

Fig. 1. Relationship between total $\mathrm{N}$ gain and $\mathrm{N}$ derived from fertilizer for $(\diamond)$ Euonymus alatus (euonymus), $(\times)$ Cornus sericea (cornus), and $(\triangle)$ Weigela florida (weigela). Data for 25-, 50-, 100-, 200-, and 300-mg. $\mathrm{L}^{-1}$ application rates are shown in $\mathbf{A}-\mathbf{E}$, respectively. Although slopes are derived from a plot of total $\mathrm{N}$ (in $\mathrm{mg}$ ) and fertilizer $\mathrm{N}$ (in $\mathrm{mg}$ ), the units are equivalent to the $\mathrm{g} \cdot \mathrm{g}^{-1}$ units presented in Table 1 .

severe overestimate of IUDF for euonymus and a minor overestimate for cornus and weigela. Interceptrelated differences for a ratio are most pronounced for small $\mathrm{x}$-axis values (Righetti et al., 2007). The cornus and weigela genera with larger total $\mathrm{N}$ content have NDFF values that are still dependent on their denominators, but much less so than euonymus. The same argument explains why deviations between slope-based and ratio-based approaches are most extreme for data at low rates of N. For high application rates, the two approaches (ratiobased NDFF and regression-based IUDF) are more similar.

Covariance ANAlysis To EVALUATE SIZE-RELATED INDIRECT EFFECTS FOR WHOLE PLANTS. When the three genera were evaluated by ANOVA at each individual $\mathrm{N}$ rate (five separate statistical analyses), $P$ values (Table 2) were in agreement with the overall evaluation presented in Table 1. Euonymus had greater NDFF than the other two genera at the three lowest $\mathrm{N}$ rates. However, when $\log _{10}$ labeled fertilizer $\mathrm{N}$ content is evaluated using $\log _{10}$ total $\mathrm{N}$ gain as a covariate at each individual $\mathrm{N}$ rate, statistical differences among genera disappear (Table 2). Similar results occur when NDFF is evaluated using $1 /$ total $\mathrm{N}$ gain as a covar-

statistically different from zero for the $25-, 50-$, and $100-\mathrm{mg} \cdot \mathrm{L}^{-1}$ application rates. This statistical difference is important because NDFF will mathematically decrease as total $\mathrm{N}$ gain increases for regression lines with positive $y$-intercepts. The fact that plots of $\log _{10}$ total $\mathrm{N}$ gain versus $\log _{10}$ fertilizer $\mathrm{N}$ (Table 1) have slopes that are statistically less than 1.0 also indicates that NDFF will decrease as $\mathrm{N}$ gain increases for the three lowest $\mathrm{N}$ rates. Indeed, NDFF is significantly related to $1 /$ total $\mathrm{N}$ gain at the three lowest $\mathrm{N}$ rates $(P<0.001$ for all three rates). A scaling effect accounts for the smaller euonymus plants having greater NDFF without differing in the incremental increase of fertilizer $\mathrm{N}$ as total $\mathrm{N}$ increases. For example, the $\mathrm{r}^{2}$ value is almost 1.0 when calculated for just the cornus and euonymus points for the $100-\mathrm{mg} \cdot \mathrm{L}^{-1}$ rate in Figure $1 \mathrm{C}$. Both genera fall on the same regression line, but there are statistical differences between these two genera in the NDFF values at the $100-\mathrm{mg} \cdot \mathrm{L}^{-1} \mathrm{~N}$ application rate (Table 1 ).

Physiological factors other than size do not account for differences in NDFF among genera. Although euonymus always has larger mean NDFF than weigela, a very large euonymus plant and a very small weigela plant would have similar NDFF. The values of the $y$-intercepts increase as $\mathrm{N}$ rate increases from 25 to $100 \mathrm{mg} \cdot \mathrm{L}^{-1}$, but the indirect effect is most severe at the lowest rate.

The IUDF presented in Table 1 is the slope of the total $\mathrm{N}$ versus labeled fertilizer $\mathrm{N}$ curves for each rate (Fig. 1). Using NDFF to approximate incremental change (IUDF) leads to a iate (data not shown). In fact, weigela appears to accumulate more fertilizer $\mathrm{N}$ than euonymus after controlling for $\mathrm{N}$ gain at the $25(P=0.07)$ and $50 \mathrm{mg} \cdot \mathrm{L}^{-1}(P=0.03)$ application rates.

Evaluation of MEAN NDFF fOR RoOTs AND Shoots. Mean values for shoot and root NDFF at different $\mathrm{N}$ rates for all three genera are shown in Table 3. Trends for differences among genera and response to $\mathrm{N}$ rate are similar to the whole plant data previously discussed. Differences in NDFF between shoots and roots are also significant (Table 3). There were also significant $\mathrm{N}$ rate $\times$ genera, $\mathrm{N}$ rate $\times$ tissue, genera $\times$ tissue, and $N$ rate $\times$ genera $\times$ tissue interactions. Significant differences related to $\mathrm{N}$ rate are likely direct. However, significant differences in NDFF between genera and tissues and genera $\times$ tissue interactions are likely indirect (discussed subsequently).

Shoots generally had significantly higher ratio-based NDFF than roots. Cornus had higher shoot NDFF than root NDFF for all $\mathrm{N}$ rates. Euonymus shoots had higher NDFF than euonymus roots for all but the $100-\mathrm{mg} \cdot \mathrm{L}^{-1} \mathrm{~N}$ rate. Weigela shoots had higher shoot NDFF than root NDFF at the 100- and 200-mg. $\mathrm{L}^{-1}$ $\mathrm{N}$ rates. However, statistical differences for NDFF between plant parts do not necessarily imply that there are physiological differences that alter the portion of new $\mathrm{N}$ uptake that roots and shoots derive from the fertilizer. Once again, regression and covariance analyses (discussed subsequently) support a different conclusion than what mean NDFF values suggest. 
Table 2. Statistical differences for covariate adjusted mean values for $\log _{10}$ total fertilizer $\mathrm{N}\left(\log _{10}\right.$ total $\mathrm{N}$ gain as covariate) for Cornus sericea (cornus), Euonymus alatus (euon.), and Weigela florida (weigela) grown in containers at different $\mathrm{N}$ rates. ${ }^{\mathrm{z}}$

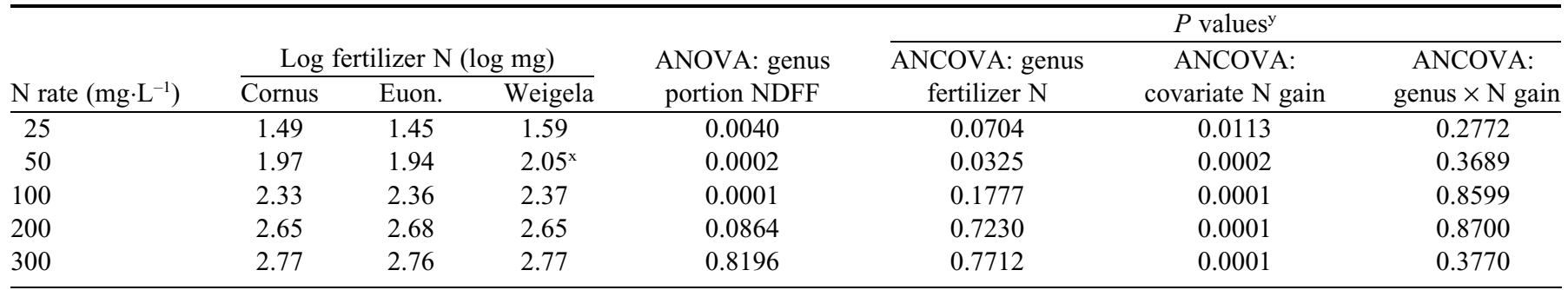

${ }^{\mathrm{z}} \mathrm{ANOVA} P$ values for portion N derived from fertilizer (NDFF) and ANCOVA $P$ values for genera effects (covariate adjusted $\log _{10}$ fertilizer $\mathrm{N}$ ), covariate effects and interactions are also shown.

${ }^{y}$ Because it was not possible to obtain homogeneity of slope when multiple $\mathrm{N}$ rates were evaluated, ANOVAs on portion NDFF and the corresponding ANCOVAs on $\log _{10}$ fertilizer $\mathrm{N}$ were conducted separately for each $\mathrm{N}$ rate. ANCOVA $P$ values for genus and covariate effects were calculated after the insignificant genus $\times$ covariate interaction was removed from the covariate model.

${ }^{\mathrm{x}}$ Only the covariate adjusted $\log _{10}$ fertilizer $\mathrm{N}$ value for weigela at the $50-\mathrm{mg} \cdot \mathrm{L}^{-1} \mathrm{~N}$ rate significantly differed from the other genera at similar $\mathrm{N}$ rates $(P<0.05)$.

ANOVA $=$ analysis of variance; ANCOVA = analysis of covariance.

REgRESSION EVALUATIONS OF THE PORTION OF NITROGEN DERIVED FROM FERTILIZER FOR ROOTS AND SHOOTS. Best fit linear regression equations for the $\log _{10}$ total $\mathrm{N}$ gain versus $\log _{10}$ labeled fertilizer $\mathrm{N}$ for both root and shoot tissues at all five $\mathrm{N}$ application rates are shown in Figure 2. At all application rates, fertilizer $\mathrm{N}$ increases as total $\mathrm{N}$ increases for both root and shoot tissues. The slopes of the functions representing root and shoot tissues increase as application rate increases. This supports the trends apparent in Table 3 and suggests that $\mathrm{N}$ rate directly alters $\mathrm{N}$ accumulation in both roots and shoots.

At the $25-\mathrm{mg} \cdot \mathrm{L}^{-1} \mathrm{~N}$ rate, almost all shoot tissue data points fall below the curve describing the relationship between total $\mathrm{N}$ and labeled fertilizer $\mathrm{N}$ for root tissues. The large shoot tissues (high in total $\mathrm{N}$ ) have less $\mathrm{N}$ derived from the fertilizer than root tissues with similar total $\mathrm{N}$. At the $50-\mathrm{mg} \cdot \mathrm{L}^{-1}$ application rate, root and shoot tissues appear to fall on the same regression line, suggesting that root or shoot tissues with similar $\mathrm{N}$ amounts will have similar amounts of fertilizer-derived $\mathrm{N}$. At the $100-\mathrm{mg} \cdot \mathrm{L}^{-1} \mathrm{~N}$ rate, with few exceptions, root and shoot tissues appear to fall on the same regression line, again suggesting that root or shoot tissues with similar $\mathrm{N}$ amounts will have similar amounts of fertilizer-derived N. The exceptions are one weigela data point, which appears to be an outlier, and all the data points for cornus roots. These data points appear to fall below regression lines representing both tissues from the other genera. Although the slope and intercept for the regression line representing cornus roots is not significantly different from the other two regression lines, the trend suggests that cornus roots may accumulate $\mathrm{N}$ differently (discussed subsequently) than the tissues from the other genera. At the 200- and $300-\mathrm{mg} \cdot \mathrm{L}^{-1} \mathrm{~N}$ rates, root tissue data points appear to fall under the curve describing the relationship between total $\mathrm{N}$ gain and labeled fertilizer $\mathrm{N}$ for shoot tissues, but $y$-intercepts are not significantly different. At all $\mathrm{N}$ rates, functions describing root and shoot tissues have similar slopes. At the $25-\mathrm{mg} \cdot \mathrm{L}^{-1}$ $\mathrm{N}$ rate, $y$-intercepts for functions describing root and shoot tissues are statistically different $(P<0.05)$.

Interpretations based on the statistical evaluations (Table 3 ) for the mean ratio-based NDFF presented differ from the regression analysis discussed previously. The fact that roots have more $\mathrm{N}$ derived from the fertilizer than shoots at the $25-\mathrm{mg} \cdot \mathrm{L}^{-1} \mathrm{~N}$ rate, roots and shoots have about the same $\mathrm{N}$ derived from the fertilizer at the $50-$ and $100-\mathrm{mg} \cdot \mathrm{L}^{-1} \mathrm{~N}$ rates (with the exception of cornus roots at the $100-\mathrm{mg} \cdot \mathrm{L}^{-1} \mathrm{~N}$ rate) demonstrates the confounding effects that tissue size has on the interpretation of NDFF means.

COVARIANCE ANALYSIS TO EVALUATE SIZE-RELATED INDIRECT EFFECTS FOR ROOTS AND SHOOTS. When the roots and shoots of all three genera were evaluated by ANOVA at each individual $\mathrm{N}$ rate, the mixed model $P$ values (Table 4 ) were in general agreement with the overall evaluation (ANOVA for combined $\mathrm{N}$ rates) presented in Table 3 . The $P$ values in Table 4 and mean

Table 3. Statistical differences for mean values for the portion of the total nitrogen in shoots and roots derived from fertilizer (NDFF) for Cornus sericea (cornus), Euonymus alatus (euon.), and Weigela florida (weigela) grown in containers.

\begin{tabular}{|c|c|c|c|c|c|c|}
\hline \multirow[b]{2}{*}{$\mathrm{N}$ rate $\left(\mathrm{mg} \cdot \mathrm{L}^{-1}\right)$} & \multicolumn{3}{|c|}{ Shoot NDFF $\left(\mathrm{g} \cdot \mathrm{g}^{-1}\right)$} & \multicolumn{3}{|c|}{ Root NDFF $\left(\mathrm{g} \cdot \mathrm{g}^{-1}\right)$} \\
\hline & Cornus & Euon. & $\overline{\text { Weigela }}$ & Cornus & Euon. & $\overline{\text { Weigela }}$ \\
\hline 25 & $0.217 \mathrm{a}^{\mathrm{z} * \mathrm{y}}$ & $0.315 \mathrm{~b}^{*}$ & $0.193 \mathrm{a}$ & $0.170 \mathrm{a}$ & $0.290 \mathrm{c}$ & $0.210 \mathrm{~b}$ \\
\hline 50 & $0.448 \mathrm{~b}^{*}$ & $0.528 \mathrm{~b}^{*}$ & $0.383 \mathrm{a}$ & $0.297 \mathrm{a}$ & $0.479 \mathrm{c}$ & $0.374 \mathrm{~b}$ \\
\hline 200 & $0.881 \mathrm{a}^{*}$ & $0.842 \mathrm{a}^{*}$ & $0.814 \mathrm{a}^{*}$ & $0.698 \mathrm{a}$ & $0.784 \mathrm{a}$ & $0.757 \mathrm{a}$ \\
\hline 300 & $0.947 \mathrm{a}^{*}$ & $0.842 \mathrm{a}^{*}$ & $0.814 \mathrm{a}$ & $0.826 \mathrm{a}$ & $0.794 \mathrm{a}$ & $0.846 \mathrm{a}$ \\
\hline $\begin{array}{l}\text { Quadratic statistical } \\
\text { significance }\end{array}$ & $* * * \mathrm{x}$ & *** & $* * *$ & $* * *$ & $* * *$ & $* * *$ \\
\hline
\end{tabular}

${ }^{\mathrm{z}}$ Values for NDFF for the same $\mathrm{N}$ rate and tissue followed by the same letter are not statistically significant $(P>0.05)$.

${ }^{\mathrm{y}}$ An asterisk indicates that values for shoot tissues are significantly different from values for root tissues for the same $\mathrm{N}$ rate and genus $(P<0.05)$.

${ }^{\mathrm{x}} \mathrm{A}$ triple asterisk indicates that the relationship for values in the same column and $\mathrm{N}$ rate is statistically significant $(P<0.001)$. 

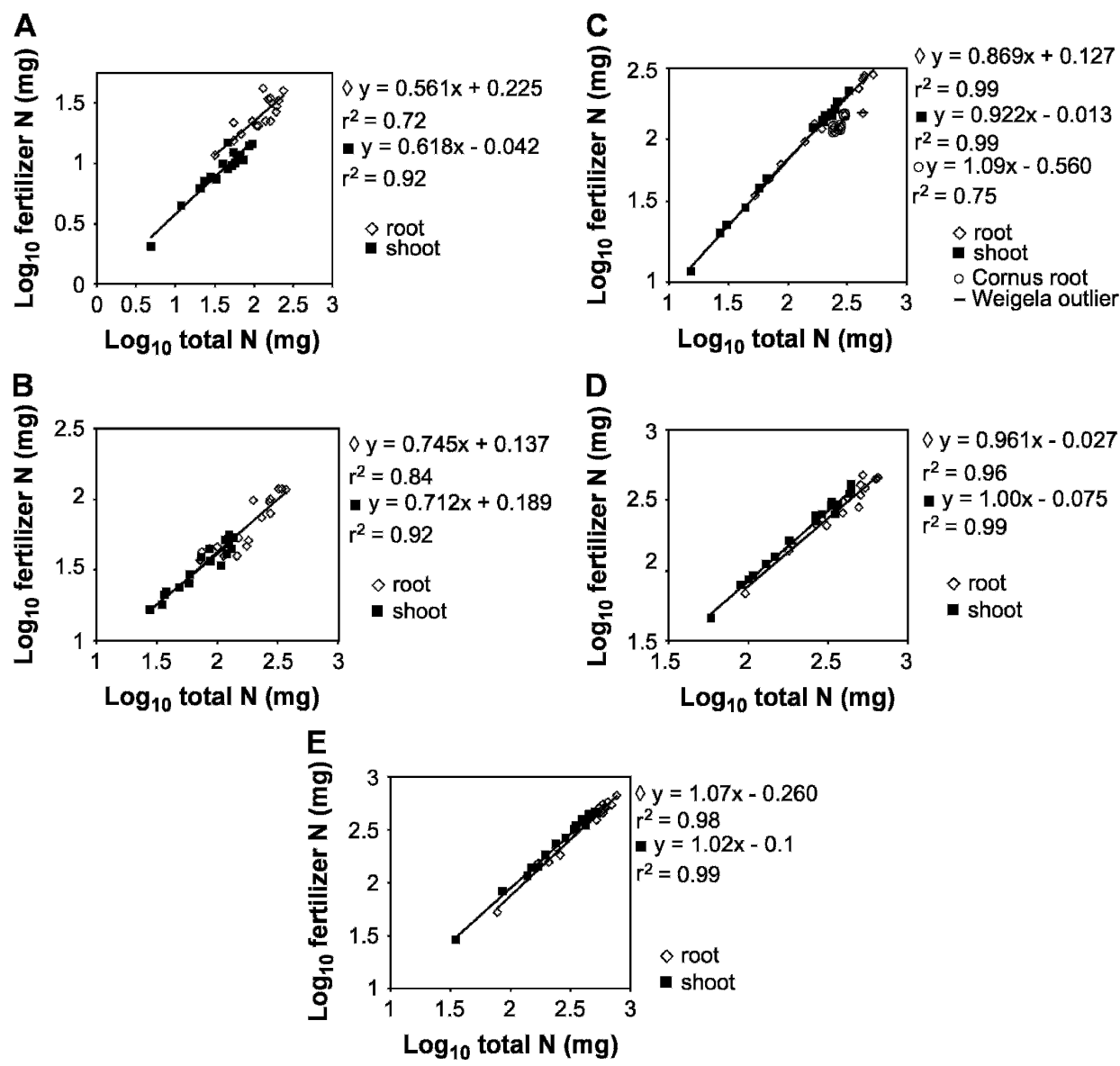

Fig. 2. Relationship between $\log _{10}$ total $\mathrm{N}$ gain and $\log _{10} \mathrm{~N}$ derived from fertilizer for $(\diamond)$ root and $(\square)$ shoot tissues for Cornus sericea (cornus), Euonymus alatus (euonymus), and Weigela florida (weigela). Best-fit regression equations are shown. Data for 25-, 50-, 100-, 200-, and 300-mg. $\mathrm{L}^{-1}$ application rates are shown in $\mathbf{A}-\mathbf{E}$, respectively. Separate regression equations for Cornus roots and the roots of the other two genera are presented in $\mathrm{C}$.

differences (data not shown) confirm that euonymus had the highest NDFF at the three lowest $\mathrm{N}$ rates for both root and shoot tissues. Shoot tissues also had significantly higher NDFF than root tissues when each individual $\mathrm{N}$ rate was analyzed.

Statistical differences among genera for both root and shoot tissues, at the three lowest $\mathrm{N}$ rates, generally disappear when $\log _{10}$ labeled fertilizer $\mathrm{N}$ content is evaluated using $\log _{10}$ total $\mathrm{N}$ gain as a covariate (Table 4). There is a trend for cornus roots to accumulate less fertilizer $\mathrm{N}$ than the roots of the other two genera at the $100-\mathrm{mg} \cdot \mathrm{L}^{-1}$ $\mathrm{N}$ rate. Unlike the portion NDFF values (Table 3 ), the covariate adjusted means for euonymus are not significantly greater than the other two genera. The ANCOVA supports the regression analysis (Fig. 2) and suggests, as was the case for total plant data (Table 1), that genera differences for both root and shoot tissues are indirect. Similar results occur when NDFF is evaluated using $1 /$ total $\mathrm{N}$ gain as a covariate (data not shown).

The NDFF ratio tended to be lower in the tissues with greater $\mathrm{N}$ assimilation for both tissue types at the three of the lowest $\mathrm{N}$ rates [NDFF significantly related to $1 /$ total $\mathrm{N}$ gain $(P<0.05$ for both root and shoot tissues at all three $\mathrm{N}$ rates)]. Euonymus is a smaller genus than weigela or cornus and does not accumulate as much $\mathrm{N}$; therefore, it has greater NDFF in both root and shoot tissues strictly attributable to its relatively small size.

Statistical differences between root and shoot tissues for covariate adjusted $\log _{10}$ labeled fertilizer $\mathrm{N}$ content (Table 4) do not support the NDFF analyses (Table 3). At the $25-\mathrm{mg} \cdot \mathrm{L}^{-1} \mathrm{~N}$ rate, the ANOVA on NDFF and ANCOVA on $\log _{10}$ labeled fertilizer $\mathrm{N}$ content support opposite conclusions. The NDFF means suggest that shoots accumulate more fertilizer $\mathrm{N}$ than roots, whereas the covariate adjusted total $\mathrm{N}$ content (discussed subsequently) suggests that roots tend to accumulate more $\mathrm{N}$ than shoots.

Table 4. Mixed-model ANOVA $P$ values for portion nitrogen derived from fertilizer (NDFF) and mixed model ANCOVA $P$ values for $\log _{10}$ fertilizer $\mathrm{N}\left(\log _{10}\right.$ total $\mathrm{N}$ gain covariate) for Cornus sericea, Euonymus alatus, and Weigela florida grown in containers at different $\mathrm{N}$ rates. ${ }^{\mathrm{z}}$

\begin{tabular}{|c|c|c|c|c|c|c|c|c|c|c|}
\hline \multirow[b]{2}{*}{$\mathrm{N}$ rate $\left(\mathrm{mg} \cdot \mathrm{L}^{-1}\right)$} & \multicolumn{3}{|c|}{ ANOVA: Portion NDFF $P$ values ${ }^{y}$} & \multicolumn{7}{|c|}{ ANCOVA: $\log _{10}$ fertilizer $N P$ values } \\
\hline & Genus (G) & Tissue $(\mathrm{T})$ & $\mathrm{G} \times \mathrm{T}$ & $\mathrm{G}$ & $\mathrm{T}$ & $\mathrm{G} \times \mathrm{T}$ & Total N (TN) & $\mathrm{TN} \times \mathrm{G}$ & $\mathrm{TN} \times \mathrm{T}$ & $\mathrm{TN} \times \mathrm{G} \times \mathrm{T}$ \\
\hline 25 & 0.0076 & 0.0006 & 0.0011 & & & & 0.0016 & 0.0684 & 0.6799 & 0.7992 \\
\hline $25{\text { (two genera })^{\mathrm{x}}}$ & 0.0056 & 0.0006 & 0.1517 & 0.1482 & 0.0617 & 0.1461 & 0.0014 & 0.5545 & 0.9561 & 0.6032 \\
\hline 100 & 0.0001 & 0.0001 & 0.0006 & 0.0603 & 0.0034 & 0.0034 & 0.0001 & 0.4644 & 0.4684 & 0.8780 \\
\hline 200 & 0.6847 & 0.0001 & 0.0001 & 0.7450 & 0.0002 & 0.0003 & 0.0001 & 0.4200 & 0.1215 & 0.2671 \\
\hline 300 & 0.3993 & 0.0001 & 0.0177 & 0.5931 & 0.0001 & 0.0066 & 0.0001 & 0.8845 & 0.6270 & 0.7024 \\
\hline
\end{tabular}

${ }^{\mathrm{z}}$ Genera effects, tissue effects, covariate effects, and interactions are shown.

${ }^{\mathrm{y} B e c a u s e}$ it was not possible to obtain homogeneity of slope when multiple $\mathrm{N}$ rates were evaluated, ANOVAs on portion NDFF and the corresponding ANCOVAs on $\log _{10}$ fertilizer $\mathrm{N}$ were conducted separately for each $\mathrm{N}$ rate. ANCOVA $P$ values for genus, tissue, genus $\times$ tissue, and covariate effects were calculated after genus $\times$ covariate, tissue $\times$ covariate, and genus $\times$ tissue $\times$ covariate interactions, when insignificant, were removed from the covariate model.

${ }^{\mathrm{x}}$ At the $25-\mathrm{mg} \cdot \mathrm{L}^{-1} \mathrm{~N}$ rate, it was not possible to obtain homogeneity of slope when $W$. florida was included in the analysis. Therefore, both the ANOVA and ANCOVA analyses were conducted only on the combined C. sericea and E. alatus data.

$\mathrm{ANOVA}=$ analysis of variance; ANCOVA $=$ analysis of covariance. 
Homogeneity of slope could not be demonstrated (Table 4) at the $25-\mathrm{mg} \cdot \mathrm{L}^{-1} \mathrm{~N}$ rate when weigela was included in the analysis. This occurred because weigela accumulated more fertilizer $\mathrm{N}$ at similar total $\mathrm{N}$ levels than the other two genera (data not shown). However, when the two remaining genera are analyzed, there is a trend $(P=0.0617)$ for greater, rather than less, fertilizer $\mathrm{N}$ accumulation in roots than shoots (covariate adjusted $\log _{10}$ fertilizer $\mathrm{N}$ means of $1.066,1.166$, 1.002 , and 1.031 for cornus roots, euonymus roots, cornus shoots, and euonymus shoots, respectively). Again, the covariance analysis at the $25-\mathrm{mg} \cdot \mathrm{L}^{-1} \mathrm{~N}$ rate is consistent with the regression analyses. The regressions in Figure 2A suggest that at similar total $\mathrm{N}$ gain levels, roots would accumulate more rather than less labeled fertilizer $\mathrm{N}$ than shoots. Unlike the NDFF values in Table 3, the covariance analyses at the 50and $100-\mathrm{mg} \cdot \mathrm{L}^{-1} \mathrm{~N}$ rates (Table 4 ) do not suggest that shoots generally accumulate more fertilizer $\mathrm{N}$ than roots. Only for cornus at the $100-\mathrm{mg} \cdot \mathrm{L}^{-1} \mathrm{~N}$ rate do shoots accumulate more fertilizer $\mathrm{N}$ than roots $(P=0.03)$ when adjusted means $\left(\log _{10}\right.$ fertilizer $\mathrm{N}$ ) for tissues are compared for the three low $\mathrm{N}$ treatments (data not shown). However, at the two highest $\mathrm{N}$ rates. both NDFF and covariate adjusted $\log _{10}$ labeled fertilizer $\mathrm{N}$ content means generally support the same conclusion in which shoots accumulate more labeled fertilizer N. Genera $\times$ tissue interactions were significant in the ANCOVA analyses of the four highest $\mathrm{N}$ rates (Table 4). Cornus tended to have the largest differences between root and shoot tissues, whereas weigela tended to have the smallest differences (data not shown).

Larger tissues with high total $\mathrm{N}$ have less NDFF than smaller tissues with low total N. Statistical differences in NDFF are real, but it is difficult to separate size-related differences from any possible additional physiological differences between roots and shoots. In Table 3, the NDFF for small shoots is compared with NDFF of much larger roots that have greater total N. Mean NDFF values include size effects that can either magnify or obscure other physiological differences. Both the regression and covariate analyses support similar conclusions and more accurately reflect direct effects. However, in some cases, the covariate approaches have better statistical precision. For example, differences between root and shoot tissues were detected at the 200 - and $300-\mathrm{mg} \cdot \mathrm{L}^{-1} \mathrm{~N}$ rates with the covariate approach (Table 4), whereas the regression lines for the two tissues (Fig. 2D, E) were not significantly different.

REASONS FOR POSITIVE $\boldsymbol{Y}$-INTERCEPTS. The experiments were not designed to determine the cause of positive $y$ intercepts, but several theoretical explanations are presented. Positive intercepts are not conceptually possible. No fertilizer $\mathrm{N}$ can be present when total $\mathrm{N}$ is zero. However, real data sets can easily produce nonzero $y$-intercepts (Righetti et al., 2007).

It is unlikely that the fertilizer $\mathrm{N}$ was overestimated with a systematic analysis error. Repeat analyses produced similar results. Although single plant replicates were used in this study, it is possible that the composite samples of shoots and roots could be represented by a wedge-shaped distribution in a plot of total $\mathrm{N}$ versus labeled fertilizer $\mathrm{N}$ if individual shoots or roots were analyzed. Wedge-shaped distributions are common (Thomson et al., 1996). Averaging values for individual shoots or roots of different sizes could produce positive intercepts (Righetti et al., 2007). However, because individual root and shoot tissues were not analyzed, this explanation cannot be supported experimentally.
The data also may represent a situation in which a curvilinear function with a zero intercept could approximate the relationship between total $\mathrm{N}$ and labeled fertilizer $\mathrm{N}$ if data were not limited to a linear range. The "real" curves could likely bend and eventually pass through zero, but there is insufficient data to define the response curve at low values of total N. Data described by a linear equation with a nonzero $y$-intercept can often be described with a curvilinear power function $y=c x^{\mathrm{b}}$ that rapidly bends beyond the data range.

Only for the smallest plant tissues (roots at the $25-\mathrm{mg} \cdot \mathrm{L}^{-1}$ application rate) did a curvilinear function $\left(y=-0.0012 \mathrm{x}^{2}+\right.$ $\left.0.235 \mathrm{x}+1.66 ; \mathrm{r}^{2}=0.83\right)$ that approached a near zero intercept provide a better fit than the linear equations shown. Although both function types reflect similar phenomena, it may be easier to detect near-linear functions with positive intercepts than to experimentally identify curvilinear relationships that pass through the origin.

A total $\mathrm{N}$ uptake rate that increases faster than fertilizer $\mathrm{N}$ uptake rates could explain the scaling issues this article addresses. Faster total $\mathrm{N}$ accumulation could occur if large plants (with high total $\mathrm{N}$ ) have either less efficient fertilizer $\mathrm{N}$ utilization or more efficient utilization of organic N. Of these two possibilities, we suspect the latter is more probable.

Nonfertilizer $\mathrm{N}$ was an important $\mathrm{N}$ source for plants at the low $\mathrm{N}$ application rates. Slope-based estimates (Table 1) of the amount of IUDF were only $0.12,0.29$, and $0.56 \mathrm{~g} \cdot \mathrm{g}^{-1}$, respectively, for the three lowest rates. Input from irrigation water was small, representing less than $25 \%, 12.5 \%$, and $6.25 \%$ of the amount of added fertilizer $\mathrm{N}$ for the 25-, 50-, and $100-\mathrm{mg} \cdot \mathrm{L}^{-1} \mathrm{~N}$ application rates, respectively. Therefore, a large portion of the $\mathrm{N}$ in plants, $\approx 0.88,0.71$, and $0.45 \mathrm{~g} \cdot \mathrm{g}^{-1}$, respectively, for the three lowest rates, that came from nonfertilizer sources likely came from the media. NDFF values (Table 1) are higher than IUDF estimates, but both values suggest that nonfertilizer sources were important.

Plants grew in the container media for over 1 year. Although extensive measurements were not taken, we observed that much of the growth at low $\mathrm{N}$ rates occurred late in the growth cycle. Larger plants also appeared to produce more of their total growth late in the growth cycle. Because the bark media had very high $C: N$ ratios $(\approx 400: 1)$, it is likely that net mineralization was small or negligible early in the growth cycle, but over time, as microbial transformations occurred in this moist environment, net $\mathrm{N}$ mineralization increased.

Smaller plants with less growth and uptake late in the growth cycle likely had less access to the unlabeled $\mathrm{N}$ derived from the media. Smaller plants also may have had less access to the unlabeled $\mathrm{N}$ delivered in the late-season irrigation water. Reduced availability of $\mathrm{N}$ from the media and irrigation water for small plants could produce a "real" curvilinear total $\mathrm{N}$ versus labeled fertilizer $\mathrm{N}$ response curve. This could explain the apparently linear functions with positive intercepts for the range of data we collected. Differences among plants in the utilization of the different $\mathrm{N}$ pools may have occurred.

\section{Conclusion}

The incremental increase in fertilizer $\mathrm{N}$ for each gain in total $\mathrm{N}$ was generally constant within an $\mathrm{N}$ rate for all genera over the range of data collected. The $y$-intercepts of a total $\mathrm{N}$ versus fertilizer $\mathrm{N}$ plot were positive. Therefore, differences 
in NDFF among genera were mostly size-related rather than incited by other physiological causes. In almost all cases, a very large euonymus plant and a very small weigela plant would have similar NDFF. Apparent NDFF differences between tissues at the three lowest $\mathrm{N}$ rates are also mostly size-related. Indirect size-related differences in NDFF can artificially enhance or reduce other physiological differences among tissue types. Only $\mathrm{N}$ rate directly enhanced fertilizer $\mathrm{N}$ accumulation.

The ratio-based NDFF is an accurate evaluation of the amount of $\mathrm{N}$ in a plant or tissue that is derived from fertilizer, but it does not necessarily reflect incremental differences in the portion of $\mathrm{N}$ uptake that is fertilizer-derived. Although widely used, the ratio-based NDFF expression should be cautiously interpreted. If a plot of total $\mathrm{N}$ versus labeled fertilizer $\mathrm{N}$ does not pass through the origin, it is misleading to statistically compare NDFF values for plants or tissues with different amounts of total N. Statistical differences are often indirect and size-related.

The problems associated with ratio-based NDFF evaluations are not limited to the data set discussed. We have found similar interpretative difficulties in many data sets (data not shown) and suspect that nonzero $y$-intercepts are common. In much of the literature in which NDFF values are presented, it is not possible to tell if total $\mathrm{N}$ versus labeled fertilizer $\mathrm{N}$ regression lines pass through the origin.

Because the data easily can be analyzed several ways, simultaneously evaluating data with ratio-based NDFF, covariates, and regression is appropriate. A researcher can then evaluate the relevance of statistically significant differences in the ratiobased NDFF. The difference between size- or total N-related indirect effects and other physiological effects can be assessed. Although a small number of replications are generally sufficient to obtain statistically significant results with ANOVA, increasing the number of replications will strengthen the use of a regression analysis.

\section{Literature Cited}

Atchley, W.R., C.T. Gaskins, and D. Anderson. 1976. Statistical properties of ratios. I. Empirical results. Syst. Zool. 25:137-148.

Brown, J.H. and G.B. West. 2000. Scaling and biology. Oxford University Press, New York.

Hauck, R.D. and J.M. Bremner. 1976. Use of tracers for soil and fertilizer nitrogen research. Adv. Agron. 26:219-266.

Horneck, D.A., J.M. Hart, K. Topper, and B. Kopsell. 1989. Methods of soil analysis used in the soil testing laboratory at Oregon State University. Agricultural Experiment Station, Oregon State University, Corvallis.

Kleiber, M. 1932. Body size and metabolism. Hilgardia 6:315-353.

Meinzer, F.C. and J. Zhu. 1998. Nitrogen stress reduces efficiency of the $\mathrm{C}_{4} \mathrm{CO}_{2}$ concentrating system, and therefore quantum yield, in Saccharum (sugarcane) species. J. Expt. Bot. 49:1227-1234.

Packard, G.C. and T.J. Boardman. 1988. The misuse of indices and percentages in ecophysiological research. Physiol. Zool. 61:1-9.

Pearson, K. 1897. On a form of spurious correlation which may arise when indices are used in the measurement of organs. Proc. Royal Soc. London 60:489-502.

Ranjith, S.A. and F.C. Meinzer. 1997. Physiological correlates of variation in nitrogen-use efficiency in two contrasting sugarcane cultivars. Crop Sci. 37:818-825.

Reich, P.B., M.G. Tjoelker, J.L. Machado, and J. Oleksyn. 2006. Universal scaling of respiratory metabolism, size and nitrogen in plants. Nature 439:457-461.

Righetti, T.L., D.R. Sandrock, B. Strik, C. Vasconcelos, P. Banados, S. Ortega-Faris, and Y. Moreno. 2007. Analysis of ratio-based responses. J. Amer. Soc. Hort. Sci. 132:3-13.

Sage, R.F. and R.W. Pearcy. 1987. The nitrogen use efficiency of $\mathrm{C}_{3}$ and $\mathrm{C}_{4}$ plants. Plant Physiol. 84:959-963.

Sandrock, D.R., T.L. Righetti, and A.N. Azarenko. 2005. Isotopic and nonisotopic estimation of nitrogen uptake efficiency in containergrown woody ornamentals. HortScience 40:665-669.

Tanner, J.M. 1949. Fallacy of per-weight and per-surface area standards and their relation to spurious correlation. J. Appl. Physiol. 2:1-15.

Thomson, J.D., G. Weiblen, B.A. Thomson, S. Alfaro, and P. Legendre. 1996. Untangling multiple factors in spatial distributions: Lilies, gophers, and rocks. Ecology 77:1698-1715. 